\title{
Towards an African Theory of Democracy
}

\section{Ademola Kazeem Fayemi}

\author{
Department of Philosophy
}

Lagos State University

Ojo, Nigeria

kcaristotle@yahoo.com

Thought and Practice: A Journal of the Philosophical Association of Kenya (PAK)

Premier Issue, New Series, Vol.1 No.1, June 2009, pp.101-126

thoughtandpractice@uonbi.ac.ke OR thoughtandpractice@gmail.com

\begin{abstract}
A bstract
This paper argues that there is a general absence of democratic theory in African political scholarship in terms of providing the underlying principles, meaning, canons and criteria of democracy in African culture. The paper exposes the conceptual errors implicit in the conflation of democracy as a concept and as practiced in different political systems. Consequently, it contends that an eclectic appraisal of our indigenous democratic values and practices as well as democratic ideas from other cultural traditions can provide a resonant African theory of democracy. The paper concludes that eclecticism is consociational in principle, and can help solve many of the contemporary socio-political problems besetting current democratic experiences in Africa.
\end{abstract}

\section{Introduction}

The question of the possibility of an African theory of democracy has been greeted with apathy in African philosophical discourse. For many African political scholars and politicians, it is absurd to think of such a possibility, because their thoughts have been patterned towards aping alien theoretical models and practices of democracy. 
However, a number of scholars have in recent times seen the need for the utilization of Africa's democratic heritage and values, rooted in her traditional past, in resolving her peculiar problems.

Since the early 1990s, the wave of democratization has been increasingly spreading across Africa. The long struggle for democracy in Africa is beginning to show results, as the continent is overcoming a legacy of authoritarianism and indifference to democratic culture. These results, according to Claude Ake (1991, 33) are too impressive and too widespread to be ignored: the popular rejection of military rule in Nigeria; the demise of apartheid in South Africa; the down fall of Samuel Doe in Liberia and Kerekou in Benin; the gains of pluralism and multi-partyism in Niger, Madagascar, Cameroon, Zambia, Algeria, Gabon, Cote d'Ivoire, Guinea, Zaria, Mozambique, Angola, the Congo and Sao Tome and Principe; the growing democratization processes in Kenya, Somalia, Sudan, Togo, Ghana, Sierra Leone, Ethiopia, Cameroon and Zimbabwe.

The forces that led to democratization were both internal and external. Internally, it was occasioned by the development failures of many African states in the 1980s, and in particular the mixed and meager accomplishments under structural adjustment programs (SAP). This demand for improved governance led to the rise of prodemocracy movements in African states, which resulted in concerted popular agitation for change. On the external front, there were serious concerns from international agencies and donor nations on the autocratic regimes in many African states. The pressure from the international scene for universal human freedom and life with dignity, coupled with promises of improved bilateral relations for non-dictatorial states, stimulated the internal drive for democratization in Africa. However, this democratization trend taking shape in many states of Africa has paradoxically not yet produced the expected result of societal transformation, as cases of civil war, genocide, poverty, corruption, insecurity among others still dot the path of many African states.

In the light of the pernicious effects of the plethora of crises currently rocking the continent, fundamental questions such as the following are being posed: 
- Is democracy sustainable in Africa?

- Why has democracy not been a sine qua non of development in Africa?

- Is it desirable to have liberal democracy in Africa, or perhaps, an indigenous African democracy in operation?

A consideration of the answers to these fundamental questions and their inherent flaws shall be examined in this paper, with a view to arriving at an African theory of democracy. The responses of scholars to these questions, which are broadly construed and categorized into three schools of thought - universalism, traditionalism and eclecticism - shall be discussed. It is envisaged that a critique of the various assumptions and presuppositions of these identified schools of thought will lead us to a plausible theory of African democracy. However, before discussing these schools of thought, it is apposite to make some clarifications on the link between democracy and development.

This paper argues that there is a general absence of democratic theory in African political scholarship in terms of providing the underlying principles, meaning, canons and criteria of democracy in African culture. The paper exposes the conceptual errors implicit in the conflation of democracy as a concept and as practiced in different political systems. Consequently, it contends that an eclectic appraisal of our indigenous democratic values and practices as well as democratic ideas from other cultural traditions can provide a resonant African theory of democracy. The paper concludes that eclecticism is consociational in principle, and can help solve many of the contemporary socio-political problems besetting current democratic experiences in Africa.

\section{The M eaning of Democracy}

As a concept and form of government, democracy is quite old. It "entails a system of government that allows the citizens freedom to decide their desires. Ancient Greece (Athens in particular) is widely regarded as the birthplace of Western democracy" (Lioba and Abdulahi 2005). It is common knowledge that the word 
democracy was derived from the Greek words demos which means "the people", and kratia which means "to rule". This in theory means a governance system by the people for the people, as opposed to rule by one despot (autocracy), or a few (oligarchy). Since ancient Greece, however, the concept of democracy has remained elusive. It is paradoxical that despite centuries of democratic governance in various parts of the globe, there is currently no univocally accepted definition of the term. There are intense debates among scholars of democracy, which can be placed into a continuum that ranges from maximalist to minimalist approaches.

The body of minimalist democratic theory is drawn from several thinkers, such as Adam Przeworski, Joseph Schumpeter, Karl Popper, William Riker, and Russel Hardin. All these scholars share a viewpoint wherein democracy neither sets conditions for its outcomes, nor characterizes itself as anything other than an electoral system. Przeworski (1999) simply defines minimalist democracy as "a system in which parties lose elections". He sees the essential value of democracy being in the peaceful transfer of power enacted through regular elections. Schumpeter (1950) argues that democracy does not entail rule by the people, but that it is ".... method by which decision-making is transferred to individuals who have gained power in a competitive struggle for the votes of the citizens". Popper (1963) asserts that democracies are a system wherein one administration can be replaced by another without bloodshed, which to him indicates elections. He rejects the concept of sovereignty in favor of elections, stating that the imperfections and uncertainties of elections are preferable to the prospect of tyranny found within sovereignty.

The above minimalist conception of democracy has been challenged by maximalists. In criticizing the minimalist conception, it is argued that without effective guarantees of civil liberties, elections do not constitute democracy, and that a "procedural minimum" for defining democracy must include not only elections, but reasonably broad guarantees of basic civil rights - such as freedom of speech, association and assembly. Thus beyond the procedural electoral minimum, maximalist scholars of democracy have identified further characteristics that must be present for these basic procedures to meaningfully constitute a democracy. Robert Dahl, for instance, advances three essential conditions for the well functioning multiparty democracy. These are: a) extensive competition by political candidates and their groups or parties; 
b) political participation that provides the choice for the electorate to select candidates in free and fair elections; and, c) civil and political liberties that enable citizens to express themselves without fear of punishment (Dahl 1971, 221). Larry Diamond, another maximalist, sees the definition of democracy as encompassing "not only a civilian, constitutional, multiparty regime, with regular, free and fair elections and universal suffrage, but organizational and informational pluralism; extensive civil liberties (freedom of expression, freedom of the press, freedom to form and join organizations); effective power for elected officials; and functional autonomy for legislative, executive and judicial organs of government” (Diamond 1988, 33).

Despite the many differences in how democracy is defined above, be it in minimalist or maximalist terms, or be it in terms of institutions, processes or outcomes, one can argue that there are two basic assumptions of democracy, namely, that all people are equal (equality) and that all people are free (liberty). In addition, certain minimum conditions must be met in order for a system to be labeled democratic. These include, among others and in no particular order, respect for human rights and the rule of law; collective deliberation, choice and participation; representative and accountable government. Democracy emphasizes that values should not be forced upon any people, and stipulates liberty, the separation of power, majority rule, and the sovereignty of the people. Democracy gives primacy to political and moral values of equality, reciprocity, and respect for the views of others.

\section{Democracy and Development}

One of the most difficult aspects of the concept of democracy is how it is practically translated into a functioning statehood in different societies. This difficulty has led to different forms and stages of democracy, as well as to the serious contention on the link between democracy and development. Claude Ake (1990, 2) for instance, sees democracy as a sin qua non for development in Africa, because he believes that there is a causal relationship between democracy and development. P.A. Nyong'o shares this view:

There is a definite correlation between the lack of democratic practices in African politics and the deteriorating economic condition. If governments are not accountable to the people they govern, then they are very likely to engage in socio-economic practices which are not 
responsive to people's needs. Questions of development and problems of economic crises cannot therefore be meaningfully discussed without discussing problems regarding the nature of state power, the form of popular participation in the processes of government and the question therefore, of democracy (Nyong'o 1990, 360).

It is important to note that the supposed causal relation between democracy and development is not as direct as suggested by Ake and Nyong'o. Democracy is no guarantee for development. Though development is a complex concept, when looked at from an aspect of the economy, which is quite often resorted to, it will be realized that the economic condition of a state can be a potential cause or consequence of democracy, rather than as a feature of democracy itself. It is also a possibility that when governance is sufficiently democratic - that is, infused with the principles of participation, rule of law, transparency and accountability, among others - all things being equal, it could go a long way toward improving the economy of a state. Development is not sustainable without transparent and accountable institutions (electoral bodies, parliaments, human rights institutions and the judiciary), national and local capacity to formulate people-centered policies, and legal and regulatory frameworks. Free, fair and regular elections are the basis of political legitimacy and the incorporation of people's development needs into public policies. Transparent legal and regulatory frameworks are necessary conditions for promoting foreign investments, and enabling developing countries to benefit from globalization. All these are not automatically a consequence of democracy. In short, while it may be unclear whether or not democratic governance enhances economic growth, it is certain that to claim an inextricable link between democracy and economic growth is to commit the fallacy of reductionism.

Democracy as a concept is not cast in iron. Consequently, in practice, it cannot be a perfect system. Even though it is not a guarantee for economic development, democracy holds more potential for enhancing and promoting human development than any other system of government. Democracy creates opportunities for the common good, and enhances capabilities of the poor and underprivileged. As such, it has an intrinsic human development value. Democratic governance has three distinct advantages over authoritarian regimes. First, democracies are better able to manage conflicts and avoid violent political change, because they provide opportunities for the people to participate in the political process of the country. Second, democracies are 
better able to forestall threats to human survival because of the checks by the opposition parties, uncensored criticism of public policies, and the fear of being voted out of office. Third, democracies lead to greater awareness of social development concerns, including health care and the rights of women and minorities. Human development performance can be enhanced through the quality of a democracy including devolution of power and resources, protection of human rights, removal of corruption and speeding up of justice (UNDP 2000, 56-58).

\section{A frica, Democratisation and U niversalism}

Francis Fukuyama's “The End of History" (originally published as an essay in The National Interest in 1989, reissued in extended form as The End of History and The Last Man in 1992) represents a universalist position on liberal democracy as the model of democratic government practicable anywhere, and in fact the most desirable to embrace. With the collapse of Communism and the "victorious" emergence of the USA from the Cold War, Fukuyama declared the liberal State as universally victorious. He argues that industrial development necessarily follows a universal pattern - that is set by the leading capitalist economies of the West - a process which will "guarantee" an "increasing homogenization of all human societies, regardless of their historical origins or cultural inheritances" (Fukuyama 1992, p.xiv). Thus, he claims that "all countries undergoing economic modernization must increasingly resemble one another: they must unify nationally on the basis of a centralized state, urbanize, replace traditional forms of social organization (like tribe, sect and family) with economically rational ones based on function and efficiency, and provide for universal education [democracy] of their citizens"( Fukuyama 1992, p.xv). Fukuyama concludes that the end has come for the struggle between different ideologies, because the universalization of Western liberal democracy has triumphed over other contesting democratic and economic alternatives.

The universalist thinking that liberal democracy is the final form of human government implies that African states cannot but adopt liberal democracy with its economic correlate, capitalism, because historically, it has proved to be the most viable, desirable and imperative for addressing the challenges of development in 
third-world nations. When examined critically, this universalist view can be seen as an imperialist attempt at inventing a new scramble for Africa. While democracy could have some universal features, the presentation of liberal democracy as the political messiah to rescue Africa out of her multifarious proclivities can be seen as an integral part of the cordiality package of neocolonialism. Fukuyama's claim on the veracity of capitalism becomes gratuitous when we factor in the recent economic crunch that is currently plaguing first world economies. Moreover, it is arguable that Fukuyama's liberal democracy cannot be the end of human history, simply because we are not at the end of human intelligence. Diverse nations have every right to construct new conceptions of democracy, which respond to their religious, economic, and social needs.

Along similar lines, Sophine Jane argues that the problem of underdevelopment in many African states is not a problem of the adoption of liberal democracy in their political orderings (Jane 2002, 17). Like Fakuyama, Jane posits that liberal democracy has the inherent potentiality of guaranteeing development in Africa. He asserts that the reason why it seems to be failing is that many African states are in haste in struggling to consolidate their democracies and impatient in achieving the developmental pace of the West. He pointed out that older democracies in the West tended to have in their favor some conditions that facilitated their societal development and consequently, consolidation of democracy. These are economic prosperity and equality (enhanced by early industrialization); a modern and diversified social structure in which a middle class plays a primary role; a national culture that tolerates diversity and prefers accommodation, and a long timespan of practicing democracy. Today, however, the pre-conditions of the older democracies do not prevail in Africa, yet many African states are struggling to consolidate their democracies, eager to ape the development pace of the West (Jane 2002, 19). Democracy in most parts of Africa is still in its infancy, with very poor and sometimes ethnically divided conditions.

The fact that a democracy is old does not mean that it is likely to be stable. Longestablished democracies face their own unique challenges. For example, in consolidated democracies, there is a growing trend of apathy and disillusionment among voters, particularly the young, whereas in emerging democracies voter turnout 
tends to be high, and many democratic movements are led by youth. Local cultures and traditions impact upon the way democratic values and systems are built and supported. It is fallacious to think that certain cultures are inherently inhospitable to democratic values and institutions. A critical analysis of the evolution of the democratic idea and practices, and of the global advance of democracy in governance, suggests that democratic governance appeals to and grows out of the universal human values of dignity and freedom. Where democratic governance has failed, it has done so more due to imperfect institutions rather than to the "unripenness" of a given country. Democracy becomes rigid, corrupt and unresponsive in the absence of periodic reform and renewal (Lipset 2000, 10).

\section{Traditionalism and Democracy in Africa}

Traditionalism as a school of thought in the discourse on the state of democracy in Africa frowns at the way democracy is practiced today in the continent. For this school, democracy as currently practiced in Africa can neither be sustained, nor can it solve the bulk of the crises besetting the continent. The apologists of this orientation have sympathy for an indigenous democratic system, which they believe is more natural to African culture. They have put forward different arguments to establish that the Western idea of democracy, which is gaining currency in contemporary Africa, should be jettisoned in lieu of our indigenous democratic culture. Some of the prominent representatives of this school of thought are Wambia dia Wamba, Marie P. Eboh, Francis Offor and Kwasi Wiredu.

Before elucidating the arguments of these scholars, it is important to have an understanding of the governance systems of pre-colonial Africa. In a bid to justify the imposition of "civilized" government" on their colonial territories, European imperialists characterized African pre-colonial political structures as autocratic and oppressive. Nevertheless, that conception was grossly inaccurate for many traditional African societies. In the case of the Yoruba for instance, an investigation into their socio-cultural history will reveal the democratic structure of their political-cultural heritage, evident in their process of choosing leadership, the principle of checks and balances, the kingdom structure, their recognition of and respect for rights and 
freedoms, and representational and participatory features of political organizations and social ordering. This is despite the fact that at the surface, it is arguable that the traditional Yoruba system of governance was monarchical, since it was headed by an individual. Using Tangwa's expression, governance in pre-colonial Yoruba society was a synthesis of "the autocratic dictatorship and popular democracy", as traditional Yoruba kingdoms exhibited a balance of authority and democracy (Tangwa 1998, 2). An anthropological description of the traditional Yoruba governance system may suffice.

Pre-colonial Yoruba societies were kingdom based. Each of the kingdoms comprised a central town and several villages. The ruler of the whole kingdom is called the Oba (king). A subordinate ruler, called Baale (village head) ruled each of the subordinate towns and villages and acknowledged the sovereignty of the king. Every town was divided into quarters, and each quarter was under the control of a quarter chief. Each quarter was made up of many large family compounds each of which housed many nuclear families (a nuclear family being a man and his wife or wives and their children) all of whom claimed descent from one ancestor (Akintoye 2009, 1). The leader or head of a family compound is called Olori ebi (family head). Each of these stratifications is interconnected with the other with respective internal governments. The choice of who governs at these various levels is done through democratic means. The choice of the Baale and the Olori ebi is mostly based on age and prominence in the ancestral tree of the village or compound, and each has a number of royal families from which the $\mathrm{Oba}$ is chosen (Salami 2006, 69).

The family group in every compound was the nucleus of the Yoruba traditional system of government. The compound had a corporate existence recognized by the whole society, with their family property rights and duties. There were usually frequent meetings where issues concerning the affairs of all members of the family group were deliberated upon. The family head, exercising his judicial authority with other elderly members of the family, settled disputes within its nuclear families, between nuclear families, and between individuals in the compound. Some family groups, in the course of the history of their town, became vested with chieftaincy titles. At the death of the family group member who held such a title, the family group meeting had to choose his successor (even though his power as chief went beyond the 
family compound); and the family group would then hand him over to the king for the investiture (Akintoye 2009, 2).

During family compound meetings, every member had full rights to express his views. In fact, it was one of the most important duties of the Family Head and the elders to ensure, not only that every member's opinion was heard, but also that every member was encouraged to express opinion. Participation was regarded as every member's duty, and any member who habitually failed to honor that duty risked becoming obnoxious in the compound. In the exercise of their powers and judicial authority in their quarters, quarter chiefs were supposed to consult the leaders of the family compounds regularly. Even at the highest levels of government, in the palace, leadership at the family compounds was treated as a very important level of authority. The title of king was hereditary in the royal family group. So too were the titles of village heads and quarter chiefs in their own particular family groups (Akintoye 2009, 3). Nevertheless, in the appointment of a king, the Yoruba political system was decidedly democratic.

When a king died, he was not automatically succeeded by his son as in many other monarchical systems. Instead, candidates for Obaship would emerge from the royal families, involving all male members of the royal family group. Thus sons (and even grandsons) of former kings, were eligible for selection as king. When they emerged, they were all treated as equal candidates to the stool, hence subject to the same rules and treatment. The power to carry out the selection on behalf of the people was vested in a standing committee of chiefs, now known as the Council of Kingmakers, in consultation with the Ifa oracle, who guides and authenticates the Council of kingmakers in their selection process. The Council of Kingmakers was all-powerful in this matter of selecting a king. Yet there decisions were not arbitrary, as there were laid down principles and norms that stringently guided their final decision on who became the $\mathrm{Oba}$ (king). First, they investigated the historical family background of each of the candidates and their respective personality traits, as well as their moral dispositions. They also allowed the general populace to lobby individually and collectively, and to express opinions on the princes, whether positive or negative. The kingmakers were obliged to give due considerations to the people's opinions. 
To be successful at these tedious processes of screening by the Council of Kingmakers, a candidate's choice must have been supported by the majority of the Council of Kingmakers upon overwhelming merits in the historical, personality and moral yardsticks used. Not until these mundane requirements were fulfilled by the candidate that the spiritual guidance of the Ifa oracle was sought. Once support was received from the Ifa oracle, other ritual processes would commence for the ascension of the king to the throne of his forefathers.

The $O b a$ as the head of the political organization of traditional Yoruba society had political, juridical, and executive power, but he did not exercise it alone. While the King occupied the highest seat of the kingdom, there existed an elaborate organization of palace officials and council of chiefs with whom he directed the affairs of the kingdom. This council included civil, military and ward chiefs, as well as heads of compounds and extended families. The council of chiefs met with the king daily in the palace to take all decisions, and to function as the highest court of appeal. After its decisions were taken, they were announced as the king's decisions. The functions of the King as the head of the council included overseeing the general health of the society, entailing internal security, issues of peace and war, and the administration of justice, with the King as the final court of appeal in the whole Kingdom, and also responsible for the management of relations with other regional Kingdoms and societies (Fadipe 1970, 206).

The power arrangement in the traditional Yoruba political setting was such that it provided checks and balances. If a king became over-ambitious and tried to establish personal power beyond the limited monarchy system, or if he became tyrannical, greedy, or otherwise seriously unpopular, some chiefs bore the constitutional duty of cautioning, counseling and rebuking him in private. If he would not mend his ways, the chiefs might take his matter before a special council of spiritual elders called Ogboni, where he would be seriously warned. If he still would not change, the quarter chiefs might alert the family heads, who might in turn inform their compound meetings. The final action would then be that certain chiefs, whose traditional duty it was to do it, would approach the king and symbolically present him with an empty calabash or parrot's eggs. The meaning of this sign is that he must compulsorily evacuate the throne and commit suicide. This final action against a king was very 
rarely taken, but every king was informed at the time of his installation that it was in the power of his subjects.

Thus the democratic import of the traditional Yoruba mode of social organization and governance is discernible from the fact that there were rules set for the choice of leaders, and governance was based on the rules and laws of the community. It was democratic to the extent that the rules were strictly followed, which made it difficult for anyone to impose himself on the society, as they ensured that to become an Oba, both the spiritual and material criteria were observed (Salami 2006, 74). There was the recognition of people's rights and freedoms. The people had the freedom to express their opinion of the $O b a$ and the rulers either directly, or through songs and other forms of symbolism during various festivals. The political system therefore accommodated the participation of both the rulers and the ruled: although the Oba was the supreme commander, every cadre of society was in various ways included in managing the affairs of the Kingdom, to the point that the activities of the Oba-incouncil at the societal level were replicated at the ward and compound levels to indeed establish a participatory democratic process in traditional Yoruba society (Salami 2006, 75).

However, it must be stated at this point that the continuum of the Yoruba indigenous system of governance was historically truncated by the advent of colonialism. The sustainability of the traditional democratic system was uncertain in view of the serious tensions that resulted from the synthesis of monarchism and democracy in traditional Yoruba culture. The Yoruba social history is replete with cases of power tussles between the executive power of the Oba (king) and other democratic institutions meant to check the excesses of the Oba. These institutions were sometimes weak in the face of the powerful and immensely influential $O b a$ superstructure within the Yoruba traditional society (Salami 2006, 76).

In the main, let us now examine the arguments of the traditionalists in the discourse on democracy in Africa. Wambia dia Wamba (1990), in his distinction between democracy in Africa and democracy for Africa, asserted that since the inception of democratization in Africa, Africans have nurtured the culture of consuming what others (the West) have articulated for them on democracy. Speaking on the African 
context, he rejects the view that democratization of Africa consists of imposing Western parliamentarism upon the continent. He is of the view that the Western multiparty system is unsuitable for the African situation. For him, one cannot democratize Africa by imposing the Western democratic system on the African situation from the top. On the contrary, he advocates for a democracy from below. Here, the concept of self-responsibilization plays a key role. For him, democracy in Africa must not be seen primarily as a mode of politics; rather, it must be viewed as a process of emancipation, self-determination and the meeting of the needs of the people. According to him, "democratization has to be considered as a process of struggle to win, defend and protect rights of people and individuals against onesidedness-including the right of self organization for autonomy and not necessarily right of participation in the state process" (Wamba 1990, 129). As a way forward, he charged Africans to reflect on the possibility of attaining African democracy.

According to Moshi and Osman (2008), liberal 'democracy failed in many parts of Africa mainly because the Western political parties aggregate primarily along class interests, whereas in Africa an established class system is mainly absent. Thus contemporary Western insistence on multiparty politics' does not consider indigenous cultural values, which makes multiparty electoral politics to degenerate into ethnic or communal conflicts. Moreover, in view of Africa's complex problems, where because of lack of a consensual norm on democracy coupled with insufficient political pressure from the African society, political regimes tend to pay less attention to elite abuse, fears of majoritarian tyranny and corruption prevail. Therefore like Wambia dia Wamba, they urged for a resurgence of African indigenous democracy.

Similarly, Eboh $(1990,167)$ argues that the Western style of democracy is not an authentic expression of contemporary African political culture, which must address so many peculiar issues. Just as one hears of Greek philosophy, Western philosophy and African philosophy, one can also talk about Greek democracy, Western democracy and African democracy, among others. This suggests that like philosophy, democracy is culturally relative. In different circumstances, various types of societies improvized different social approaches to their respective contradictions. This gave rise to different conceptions of democracy, among which were specific forms of the state and civil society, direct or indirect people's sovereignty, etc. As a consequence, Eboh 
$(1993,98)$ notes that the solution to the problem of governance in Africa lies in tackling the African socio-economic and political realities, thereby giving democracy an African flair.

Different reasons have been adduced for why democracy seems not to be working in Africa. Offor $(2006,121)$ attributed this to our refusal to accept that democracy varies from one society to another, and that by reason of this elasticity, democracy need not be practiced in strict adherence to those attributes that define it in its Western conception. For Offor, the problem with democratic practice in Africa therefore stems from a fundamental misconception that democracy as a form of government can be imported wholesale from one society to another, regardless of cultural differences. He advances the thesis that democracy is desirable and can be made to work in Africa only if the indigenous continent's democratic heritage is explored, and those ideas that define good governance are brought to bear in evolving a kind of democracy best suited for resolving Africa's peculiar problems. However, the fundamental problem with Offor's conclusion is in his false assumption that democratic ideals are culturally specific. Democratic ideals such as liberty, equality and peoples' sovereignty are universal, so that what differs are the democratic practices in different cultural and political societies.

Kwasi Wiredu (1996) is of the view that Africa's political salvation cannot come from the presently known model of majoritarian democracy, which African states are currently practicing. Majoritarian democracy involves a multy-party system of politics, in which the party that wins the most seats at the election forms the government. In such a political set-up, the losing party or parties become the opposition, singly or jointly. In this system, the minority representatives' votes are overridden by the votes of the majority. The implication of this is that the right of the minority representatives and their constituencies to meaningfully participate in the actual making of decisions is rendered nugatory. In many contemporary African states, certain ethnic groups and political parties have found themselves perpetually in the minority, consistently staged outside the corridor of power. Not only this, their fundamental human rights of decisional representation are permanently denied with impunity. This violation of the right to be well represented, Wiredu argues, is one of the most persistent causes of political instability in Africa. Consequently, in an 
attempt to provide a way out of this serious deficiency of majoritarian democracy in Africa, Wiredu explores the resonance of a non-party and consensual democracy in forestalling many of the socio-political ills in Africa:

\begin{abstract}
A non-party and consensual democratic system is one in which parties are not the basis of power. People can form political associations to propagate their political ideas and help to elect representatives to parliament. But an association having the most elected members will not therefore be the governing group. Every representative will be of the government in his personal, rather than associational capacity (Wiredu 1996, 179)
\end{abstract}

Fundamental to Wiredu's argument is the need to consider the individual's personal views, before all important decisions are made on the principle of consensus. This process of deliberation on issues rather than resorting to popular vote, is according to Wiredu, capable of promoting mutual tolerance, thereby contributing to demarginalization in a polity. Wiredu uses the example of the traditional Akan political system to illustrate the plausibility of this approach.

The complaint of the traditionalist school of thought is not new. However, the context in which it is now being voiced is novel. Traditionally, the appeal to cultural specificity has been a weapon in the hands of self-justifying elites: African despots long insisted that democracy is a stalking horse for a new colonialism. Today, however, the complaint is usually voiced by a new breed of African democrats and scholars, who are apologists of the African intellectual heritage. The rulers are now often preoccupied with simulating democracy, in the hope of attracting aid and trade, not with rationalizing its absence. The critics are understandably unwilling to conclude that Africa is not good enough for liberal democracy, but insist rather that liberal democracy is not good enough for Africa.

Reflection on the writings of scholars from the traditionalist school reveals that their concern is with the question of African identity. Their arguments are geared towards establishing that many traditional African societies were democratic, even in their monarchical social organizations, and that resorting to their values and principles in contemporary Africa would be an antidote to the plethora of Africa's problems. Furthermore, in discussing these traditional African democratic values, scholars in this school point to such precepts as consensus, human rights, social responsibility, tolerance and participation. Personally, in all these, I do not see anything distinctively African which is absent from Western democracy. 
Suffice it to note that the plea for consensus and non-party politics as espoused by Wiredu is problematic in many fronts. Wiredu's position borders on mere utopian veneration of a past that has not existed anywhere. In all societies, those in traditional Africa included, there are conflicts, which are either resolved by the stronger parties having their way, or the weaker ones being realistic enough to concede (Owolabi 2004, 439). If indeed we had the kind of consensus that Wiredu is venerating in African culture, we would not have had cases of intra-ethnic wars, civil uprisings and migration of certain segments of society. Yet cases of these abound in pre-colonial African history. Documentations of the Yoruba experiences in this regard can be found in the historical and anthropological writings of Johnson (1956), Fadipe (1970), Akinyogbin and Ayandele (1980), among others. These therefore nullify Wiredu's thesis that consensus is generally the means of decision making in traditional Africa. Even if we take for granted the existence of this democratic element of consensus in traditional Africa, we may ask whether it is still applicable to efforts at coping with the complexities of contemporary societies. Bearing in mind that traditional African societies were relatively small and therefore suited to the idea of consensus, the reality of the ultra complex state of human relations in contemporary Africa hardly leaves room for that kind of detailed consultation.

Wiredu's critique of the multiparty system, and his claim that there was none in traditional African politics, can be vitiated. While there were no formal political parties as we have in today's democracy, we cannot deny that people of like minds will always identify with one another and come together to discuss how their interests can be promoted. Such “clusters" were informal political associations, akin to today's political parties. In fact, party politics is not as inherently evil as painted by Wiredu, and his advocacy for non-party democratic polities in contemporary Africa does not in any way foreclose the possibility of the recurrence in a non-party system of those internal factors that make a multi-party system problematic.

We may also ask the extent to which people may be truly represented in a consensual representative democracy. Contrary to Wiredu's view that the major problem confronting the present model of democracy in Africa is multi-party politics, I think that the major problem of democracy in Africa is that of how the true will of the 
people can reflect in the results of elections. Wiredu clearly fails to recognise that the underlying principles and goals of consensual and non-party democracy, as he advocates, is bound to fail as long as it involves elections.

In view of the foregoing observations, it is arguable that what the traditionalists like Wiredu have succeeded in doing is to "ethnophilosophically" provide a defense of an African identity of the tradition of democracy, rather than a theory of African democracy. For the most part, they have failed to explain in concrete terms how these identified African traditional democratic values and principles (which though not entirely unique) could be incorporated into contemporary governance in Africa, such that they help to shape the contours of politics and social conditions in Africa for the good of her people. Thus apologists of the traditionalist school of thought have not succeeded in proposing an African theory of democracy, which could be compared with and/or contrasted to various Western democratic theories such as liberal, , radical, neo-idealist, elitist and pluralist democratic theories (Holden 2000).

\section{E clecticism and Democracy in Africa}

This orientation in the discourse on democracy and the African experience is an attempt to reconcile the differences between the extreme assumptions and positions of universalist and traditionalist schools of thought. The central claim of proponents of the eclectic school of thought is that much as the adoption of certain democratic values and principles in traditional African culture is welcome, we should not completely neglect the democratic ideas and practices that have been developed in other cultures, because some of the imported ideas could contribute to making democracy sustainable in Africa. E.A. Ruch, Kwame Gyekye and Kolawole Owolabi are outspoken members of this orientation.

Ruch (1981, 305) holds that our democracy must neither be a mere return to traditional Africa, nor a replication of Western modes of governance. Africa, he notes, cannot move from one extreme to the other without mapping out its own original path, while taking due cognizance of democratic development in other social formations. Gyekye (1997) urged that the sustainability of the democratization 
process in Africa is contingent on a commitment to indigenous democratic ideas and institutions, rather than alien democratic principles. While being critical of the claim that there was no full fledged democracy in traditional Africa, Gyekye said that some of the evident democratic elements in indigenous socio-political organization could be nurtured and refined for a contemporary application (Gyekye 1997, 120). He concedes that for Africa to realize political stability, we should find "ingenious ways and means of hammering the autochthonous democratic elements as well as elements inherited from alien source...into acceptable and viable democratic form in the setting of the modern world" (Gyekye 1997, 43).

In similar fashion, Owolabi posits that democratic values may exist in traditional culture as much as anti-democratic ones. Thus a return to the past in order to have a foundation of democracy in contemporary Africa should be approached with serious caution, so that we do not fall into the trap of venerating an obsolete and anachronistic culture. For him, "there is nothing forbidding us from developing a new culture of sustainable democracy from the amalgam of ideas from both our culture and that of other societies" (Owolabi 2004, 443). Owolabi sees as erroneous the traditionalist argument that because certain democratic institutions originated in the West, they cannot be successfully utilised in Africa. For him, whatever could have facilitated the workability of such democratic ideas, principles and institutions in their original ontologies, would also as a matter of passage of time, take its course in Africa.

In spite of the plausibility of the eclectic position over the claims of the universalists and traditionalists, it is unclear, going by the claims of the ecclectic school, how to achieve this eclecticism in concrete terms. For instance, there are dissenting views on the democratic credentials of traditional governance and its potential compatibility with contemporary governance. Such limitations, arising from the very complex nature of contemporary institutions and realities that may render some of the workings of indigenous values and institutions untenable, are left untreated by the apologists of eclecticism. Consequently, in the next section, we attempt to bridge this gap through an exploration of an African theory of democracy. 


\section{Towards an African Theory of Democracy}

A theory of democracy, it is expected, could either be a body of thought that provides and analyses a conception of democracy, together with an explanation and justification of the existence (or possible existence) of democracy so conceived, or an account of the workings of actual political systems that are called "democracies". In discussing an African theory of democracy, our fundamental assumption is that the practical is the meta-archetype and reflection of the theoretical. Where there is a well articulated democratic theory, the chances of success in its practical manifestation is greater than where there is none. It is in this light that the paper seeks to meet the urgent need to blaze the trail in developing an African theory of democracy. The discussion below also presupposes that such a theory will participate in the universal essence of democracy, rather than be indifferent to it.

Contrary to Oliver Iwuchukwu's $(1998,90)$ claim that any meaningful search for an African theory of democracy must begin with a radical rejection of liberal democracy, this paper favours eclecticism, albeit with some modifications. An African theory of democracy must not only be a reflection of both traditional and contemporary African socio-cultural and ontological realities, but must also entail a critical avoidance of some misconceptions and inadequacies inherent in liberal democratic theory. The reason for the emphasis on liberal democratic theory is simply that it is the model of democracy foisted on Africa.

Given the nature of traditional African societies which were communalistic in ethos, it is expected that communalism should be one of the basic constituent elements upon which the theory would be grounded. Communalism in an African theory of democracy would entail revising the very concept of development, to mean collective well being, instead of the euro-centric equation of development with modernization, high GDP and other economic indices. Putting people at the centre of development and seeking their collective well being would promote shared material and nonmaterial benefits, mutual trust, citizen participation in decision making, and the accountability of state/government officials to the general public. Unlike liberal democratic theory where individualism, majority rule, and autonomy of elected representatives in making political decisions on behalf of the people, African 
democratic theory demands greater commitment to entrenching the communalist spirit in social organization and state management: it is more committed to strengthening popular participation in policy formulation and other governmental processes.

Where liberal democratic theory ideally entails an economic correlate and homology of advanced capitalism, African democratic theory must maintain a balance between political ideals and economic expediency. With the current global economic crunch having emanated from the leading liberal democratic state, the USA, the credibility of capitalism now faces serious skepticism. As a matter of fact, African democratic theory need not have capitalism as its economic correlate, but rather a mixed economy of socialist and capitalist orientations. This becomes imperative because the economic problems of contemporary Africa constitute a serious cog in the wheel of genuine democracy.

The veracity of the above can be further substantiated by making a distinction between democracy as a form of government and democracy as a social principle. An erroneous conception has been paraded by scholars in conceiving democracy as a form of government. Abraham Lincoln's now conventional definition of democracy as "the government of the people, by the people and for the people" has led to the popular view that democracy is a form of government. However, this definition gives no clue about the specific structure, be it political or economic, of a democratic society.

In consonance with Sophie Oluwole $(2005,420)$, democracy, adequately understood, is a theory that sets some basic [socio political] principles according to which a good government, whatever its form, must be run. Such principles include those of justice, freedom, equity, accountability, rule of law and liberty. These social principles are universal criteria for distinguishing between good and bad governments. In other words, there are features of democracy that are not culturally specific, and whose abrogation inevitably produces tyranny. To give a few examples, accountable government, the citizens' right to decide, speak and organize are essential to free political expression. Where African tradition is invoked to dilute or deny pluralism, the outcome is tyranny, however iron cast its indigenous cultural form might appear. 
It is often argued that indigenous democratic institutions, values and principles could be co-opted into a liberal democratic system (such as the current democratic experiences of South Africa, Botswana and Mauritius). However, we must note that the question of tradition touches on the identity issue, which is most uncomfortable to some intellectuals. While there clearly are important elements of tradition that are incompatible with full democratic citizenship - patriarchy, for one - it could be argued that a formal democracy that is incapable of accommodating those elements of tradition and the identities that they generate which are compatible with notions of full and equal citizenship is inadequate. Indeed, the ability to ensure that traditional authority and loyalty to it are expressed within democratic norms could be a key source of the system's strength in Africa.

The test for new democracies in Africa therefore rests on the degree to which they can recognize, perhaps even celebrate, differences in institutional forms that respect democratic essentials. The key to African democracy may not only be the recognition of the right to difference, but institutions that reward co-operation between political leaderships which articulate it. We need to be critical of concepts such as multi-party systems, electoral bodies, civil societies and justice systems in our theoretical consideration of African democracy. These ideas should be given an African cultural flair in the light of our social exigencies and values.

Given the above observations, any progress towards state-building and state management in Africa will require more than liberal democratic ideals. Justice, in whatever form of democracy, seems an essential precondition not only for liberty, but for state-building and thus for stability and economic development too. If this is agreed, then in the quest for an African theory of democracy, the search for a viable justice system must necessarily be taken into consideration.

In view of the problems of social justice in contemporary Africa vis-a-viz that of corruption, poverty and bad leadership, which seem to have defied solutions, it is imperative to appropriate relevant traditional institutions and values that define an indigenous justice system. The institution of social justice in pre-colonial Africa has a complementary relationship between traditional religion and morality. Where human knowledge and power is incapacitated, morality and religion are the ultra means of 
social justice. One way of overcoming social injustice with all its threats to sustainable democracy is to embrace the complimentary contribution of spirituality and morality, which African traditional democratic practice affords. C.S. Momoh captures this in his work, Philosophy of a New Past and an Old Future:

The present oath by our public officers during swearing-in ceremonies is a passive one. What we need is an active oath. An active oath is one .... Invoked in the name of indigenous gods, or spirits or juju... spelling out what should befall the oath taker if he willingfully and deliberately enriches himself, friends or relations by exploiting or abusing his office (Momoh 1991, 132).

There are two major objections that may be raised against the above. First, what if the religious faith of the swearer (that is, the public officer in question) does not permit swearing in the names of indigenous gods or spirits? Second, it may be argued that this suggestion is primitive, retrogressive and incongruous with contemporary democratic practice.

The veracity of these possible objections can easily be plausibly vitiated on the following grounds. First, it is irrelevant whether or not the swearer believes in indigenous gods, spirits or juju: this has nothing to do with the efficacy of the oath. Even if the swearer insists that he cannot swear based on his religious convictions, he can be made to take active oaths on the Quran or the Bible. But this has to be carried out by reading relevant passages from the relevant Holy Book, followed by an invocation of what should befall him/her immediately he/she acts contrary to the rule of law, duties and obligations of his/her position.

Second, there is nothing primitive or undemocratic about active oath-taking. In fact, apart from making indigenous religion relevant in contemporary African democracy, active oath-taking will engender faith and loyalty in the political system. As the public officer who has been actively sworn-in will be conscious of the invisible mystical force tele-guiding him/her, the citizens will be taking cues from the actions/inactions of the leaders. 
In addition, given contemporary realities, we need to note that globalization has captured democracy, capitalism and human rights. There is currently great flux around these issues in the global international relations, as well as the many challenges they have created. We cannot therefore pretend to be oblivious of these challenges in future efforts towards developing an African theory of democracy.

\section{Conclusion}

The foregoing theoretical clarification of an eclectic model of African democracy will hopefully contribute to solving some of the contemporary socio-political problems besetting current democratic experiences in Africa. However, we have to be wary of internal and external forces that may work towards vitiating its realisation. Enlightened democratic education of the citizens and commitment to participatory democracy will cushion us against internal saboteurs. On the external front, it is hoped that the global community will come to regard democracy not as a rigid structural form of government, but as a civilized value to be fostered and a principle upon which to build the new world order. What is therefore urgently required of western powers is that they correct their policy to suit the demands of the new world realities, instead of forcing the world to suit their supposed universal ideological perspectives. This pluralistic understanding of democracy is imperative, especially in the light of the multi-ethnic, religious, ideological, linguistic, regional and cultural cleavages of African states. Given the global collaborations and coalitions taking root in the wake of the $21^{\text {st }}$ century, eclecticism is a viable African theory of democracy, as it favours crosscutting cleavages, overlapping memberships and a cooperative political culture that can ensure integrated development in Africa. This consociational basis of eclecticism recognizes the primacy of the people as well as the importance of democratic institutions, and emphasizes the importance of power-sharing among different segments of society (Lijphart 1969, 208). 


\section{References}

Ake, Claude. 1990. "The Case for Democracy". The Carter Center: African Governance in the 1990s: Objectives, Reserves and Constraints . Atlanta: The Carter Center of Emory University

--. 1991. "Rethinking African Democracy". Journal of Democracy, vol.2 No.1.

Akinjogbin, I.A. andE.A. Ayandele. 1980. "Yoruba Land Up to 1800". Obaro, Ikime ed. Groundwork of Nigerian History. Ibadan: Heinemann Educational Books .

Akintoye, S.Adebanji. n.d. "The Democratic Foundations of Traditional Yoruba Government". www. YorubaNation.org

Dahl, R. 1971. Polyarchy Participation and Opposition. Newhaven: Yale University press

Diamond, L.C. 1988. Ethnicity and Democracy in Nigeria: The Failure of the first Republic. London: Macmillan press ltd.

Eboh, Marie P. 1990. "Is Western Democracy the Answer to the African Problem?" Heinz, Kimmerle and Fraz M. Wimmer eds. Philosophy and Democracy in Intercultural Perspective. Amsterdam: Rodopi

--. 1993. "Democracy with an African Flair". Quest: Philosophical Discussions, Vol.7 No.1.

Fadipe, N.A. 1970. The Sociology of the Yoruba. Ibadan: Ibadan University Press

Fakuyama, Francis. 1992. The End of History and The Last Man. New York: Penguin

Gyekye, K. 1997. Tradition and Modernity: Philosophical Reflections on the African Experience. Oxford: Oxford University Press.

Holden, Barry . 1974. The Nature of Democracy. Great Britain: Nelson.

Iwuchukwu, Oliver. 1998. "Democracy and Regional Ontologies". Oguejiofor, J.O. ed. Africa: Philosophy and Public Affairs. Enugu: Delta Publications.

Johnson, S. 1956. The History of the Yoruba. Lagos: CMS.

Lijphart, Arend. 1969. "Consociational democracy". World Politics, Vol.21 no.2, pp.207-225.

Lioba Moshi and Abdulahi A. Osman (Editors). 2005. "Democracy and Culture: An African perspective" Holler Africa! http://www.hollerafrica.com/showArticle.php?artId=260\&catId=5

Lipset, Seymour M. 2000. "Prospects for Democracy", unpublished manuscript.

Momoh, C.S. 1991. Philosophy of a New Past and An Old Future. Auchi: African philosophy projects publication

Moshi, Lioba and Abdulahi A. Osman. eds. 2008. Democracy and Culture: An African Perspective. Lagos: Adonis\& Abbey Publishers

Nyongo, P.A. 1992. "Popular Struggle for Struggle for Democracy in Africa". Caron, B. et. Al. eds. Democratic Transition in Africa. Ibadan: Credu.

Offor, Francis. 2006 ."Democracy as an Issue in African Philosophy" Oladipo, Olusegun ed. Core Issues in African Philosophy. Ibadan: Hope Publications

Oluwole, S.B. 2003. "Democracy and Indigenous Governance: The Nigerian Experience". Oguejiofor, J.O. ed. Philosophy, Democracy and Responsible Governance in Africa. Rome: LIT VERLAG Munster

Owolabi, K.A. 2003. "Can the past salvage the future? Indigenous democracy and the quest for sustainable democratic governance in Africa”. In Oguejiofor, J.O. ed. 2003.

Popper, K. 1963. The Open Society and Its Enemies. Princeton: Princeton UP. 
Przeworski, Adam. 1999. "Minimalist Conception of Democracy: A Defense". in Democracy's Value. Cambridge: Cambridge UP.

Ruch, E.A. and K.C. Anyanwu. 1981. African Philosophy: An Introduction to the main Philosophical Trends in Contemporary Africa. Rome.

Salami, Y.K. 2006. " The Democratic Structure of Yoruba Political-Cultural Heritage". The Journal of Pan African Studies, vol.1 No.6.

Schumpeter, J. 1950. Capitalism, Socialism, and Democracy. New York: Harper \& Row

Sophine, Jane. 2000. Liberal Democracy and the Requisites of Development and Political Legitimacy in Africa. Port Harcourt: Bakis publishers

Tangwa, G. 1998. "Democracy and Development in Africa: Putting the Horse Before The Cart" in Road Companion to Democracy and Meritocracy. Bellingham: Kola Tree Press

United Nations Development Programme. 2002. Deepening Democracy in a Fragmented World. New York: Oxford University Press.

Wamba, Ernest Wambia dia. 1990. "Democracy in Africa and Democracy for Africa". Kimmerle, Heinz and Fraz M. Wimmer eds. Philosophy and Democracy in Intercultural Perspective. Amsterdam: Rodopi.

Wiredu, K. 1996. Cultural Universals and Particulars. Indianapolis: Indiana University Press.

--. 2001. "Tradition, Democracy and Political Legitimacy in Contemporary Africa". Kurimoto, E. ed. Rewriting Africa: Toward Renaissance or Collapse? Osaka: The Japan Center for Area Studies. 